This article was downloaded by: [Richard Rousseau]

On: 07 January 2013, At: 14:19

Publisher: Routledge

Informa Ltd Registered in England and Wales Registered Number: 1072954 Registered

office: Mortimer House, 37-41 Mortimer Street, London W1T 3J H, UK

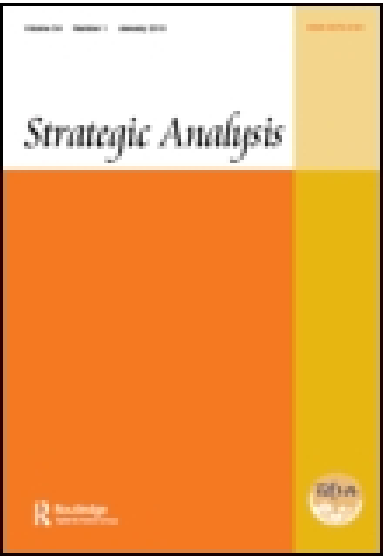

\title{
Strategic Analysis
}

Publication details, including instructions for authors and subscription information:

http:// www. tandfonline.com/loi/ rsan20

\section{Kazakhstan: Continuous Improvement or Stalemate in its Relations with China?}

Richard Rousseau

Version of record first published: 04 J an 2013.

To cite this article: Richard Rousseau (2013): Kazakhstan: Continuous Improvement or Stalemate in its Relations with China?, Strategic Analysis, 37:1, 40-51

To link to this article: http:// dx. doi.org/ 10.1080/ 09700161.2013.737599

\section{PLEASE SCROLL DOWN FOR ARTICLE}

Full terms and conditions of use: http://www.tandfonline.com/page/terms-andconditions

This article may be used for research, teaching, and private study purposes. Any substantial or systematic reproduction, redistribution, reselling, loan, sub-licensing, systematic supply, or distribution in any form to anyone is expressly forbidden.

The publisher does not give any warranty express or implied or make any representation that the contents will be complete or accurate or up to date. The accuracy of any instructions, formulae, and drug doses should be independently verified with primary sources. The publisher shall not be liable for any loss, actions, claims, proceedings, demand, or costs or damages whatsoever or howsoever caused arising directly or indirectly in connection with or arising out of the use of this material. 


\title{
Kazakhstan: Continuous Improvement or Stalemate in its Relations with China?
}

\author{
Richard Rousseau
}

\begin{abstract}
Over the last two decades Kazakhstan has implemented foreign policies aimed at improving relations with many new geopolitical actors, as well as longstanding common partners such as Russia, on which it was formerly heavily dependent. By utilising its huge hydrocarbon production potential, Kazakhstan has managed to surpass all other Central Asian states in political and economic importance. Kazakhstan has now turned its eyes to China, seeing it as an important and powerful partner in the economic, political and security spheres. This article deals with fundamental issues in Kazakhstan's relations with China.
\end{abstract}

$\mathbf{K}_{\mathrm{r} \text { a }}^{\mathrm{a}}$ azakhstan has become an important player in Central Asia's regional relations in recent years. International observers have underscored the many positive changes made by the country. Kazakhstan has achieved higher levels of real economic and social development than other regional states. In macroeconomic terms, Kazakhstan has the largest economy in Central Asia and has recorded impressive growth levels since it gained independence in 1991. It quickly recovered from the depths of the 2008/2009 world economic crisis. ${ }^{1}$ Kazakhstan's success is worth underscoring, as it is the only Central Asian country that appears in the list of countries with a high level of human development. ${ }^{2}$

However, it seems that a well-coordinated effort is being made by Astana and European Union members to overestimate the country's achievements, while conscientiously ignoring its problems. ${ }^{3}$ Western pundits also sometimes seem unwilling to criticise the 'Kazakhstani path'4 of development, although the country still has serious infrastructure problems, ${ }^{5}$ an authoritarian political system and an insufficient diverse economic base. ${ }^{6}$ It should be apparent to all stakeholders that, regardless of how impressive Kazakhstan's economic performance might appear at first glance, there is room for further improvement. The country is still largely dependent on its neighbours in various economic sectors and is continuously seeking opportunities to sustain its growth through regional and global economic cooperation. In that sense, China-Kazakhstan relations are especially important, not only in terms of overall trade turnover between the two countries, but because of the sustainability of both the 'Kazakhstani path' and Central Asia's stability.

Dr. Richard Rousseau is Associate Professor and Chairman, Department of Political Science and International Relations at Khazar University, Baku, Azerbaijan. 


\section{Kazakhstan-China relations}

Political relations between Kazakhstan and China have been cordial since 1991, the year Kazakhstan achieved independence. Old disputes over their common border have been settled and closer political contacts established. Chinese and Kazakhstani officials often meet to discuss bilateral issues and, according to Astana, ' . . . developing and maintaining good neighborly relations with China is a top priority' ${ }^{7}$ Both countries are members of the Shanghai Cooperation Organisation (SCO) and other regional and sub-regional groupings committed to promoting political cooperation, economic development and security. This strong reciprocal support is deemed essential to achieve some of their most important mutual foreign policy goals. For instance, Kazakhstan supports Beijing's 'One China' policy, thus supporting Beijing's official position on Taiwan and Tibet, ${ }^{8}$ while China backs Kazakhstan's almost two-decade-long bid to become a member of the World Trade Organisation (WTO). ${ }^{9}$

Equally positive are their bilateral economic relations, which have been intensifying for many years. China's willingness and ability to invest in Kazakhstan has been the main factor driving continual improvement in their trade relations. ${ }^{10}$ Impressive figures support these economic relations. In early 2011, for example, Beijing made a loan worth $\$ 1.7$ billion to the Kazakhstani National Welfare Fund (Samruk-Kazyna) and another worth $\$ 5$ billion to the Kazakhstani petrochemical industry, in addition to pledging to buy Kazakhstani uranium for an estimated $\$ 8$ billion. $^{11}$

Astana welcomes this uptick in the Chinese influence, as it contributes to diversifying the country's economy. Mutual trade relations were for many years concentrated in gas and oil exports from Kazakhstan to China. However, they have now entered into a process of diversification, and positive outcomes are expected from further economic integration between the two countries, especially in the border regions. ${ }^{12}$

Improved bilateral relations underscore these beneficial developments and might in the midterm help Kazakhstan consolidate its achievements. Since 2011 Kazakhstani and Chinese state officials have come together several times to discuss economic, political, cultural and security issues. In June 2011, Chinese President Hu Jintao and Kazakhstani President Nursultan Nazarbayev discussed the specifics of their security partnership, signed in 2005, and affixed their signatures on a document on 'Development of an All-Round Strategic Partnership', which stipulates a commitment to enhance bilateral trade and increase the frequency of meetings between top officials. ${ }^{13}$ Since the beginning of the 2000s Kazakhstan-China relations have been put on a strong footing. Nazarbayev and Hu Jintao, when they meet, leave the impression of sharing a deep understanding. Kazakhstan's presidency of the SCO in the second half of 2011 provided many opportunities for the two heads of state to discuss face-to-face various aspects of bilateral cooperation. Chinese officials have repeatedly expressed satisfaction with the evolution of bilateral trade relations in recent times and strongly supported the opening of the Khorgos International Centre of Boundary Cooperation, a transnational free trade centre on the border of Kazakhstan and China, spanning a 3.36 million $\mathrm{m}^{2}$ area of Chinese territory and 1.6 million $\mathrm{m}^{2}$ area of Kazakhstani land. ${ }^{14}$

Kazakhstani and Chinese officials have ample reason to be content with the trade volumes between the two countries. In 2011, the bilateral trade volume amounted to $\$ 20$ billion, up from a disappointing $\$ 8.3$ billion in 2006 . This is a significantly larger volume than the trade turnover between Kazakhstan and Russia, two countries that are trying to boost their trade through a customs union. ${ }^{15}$ Initially, Astana and Beijing set the goal of reaching a trade volume of $\$ 15$ billion by 2015 . Fortunately, the value 
of bilateral trade is already, in the first quarter of 2012, $\$ 5$ billion above the planned level. ${ }^{16}$ In addition to trade, Kazakhstan's friendship is also essential for China since it is a major transit country. For instance, the improvement of the railway connection between north-west China and south-east Kazakhstan and onward into Russia and Western Europe was at the top of the agenda in their bilateral discussion.

These developments indicate that Kazakhstan is an increasingly important player in China's strategy in the Central Asia region, while Russia's influence in that region is steadily declining in relative terms. China, Turkey and, to a much lesser extent, Iran are making rapid gains at the expense of Russia. This trend is evidenced both by data, as noted above, and by changes observable in both domestic markets and traditional bazaars across the region. The increasing Chinese presence is even changing the lifestyles of ordinary people. The flood of cheap and affordable Chinese goods has allowed Central Asians, even in the smallest and most remote villages, to buy products that they previously had never dreamed of seeing. In all probability, Russia will become progressively less able to hinder China's penetration into the region. Commercially, the future does not look enviable for Moscow as by 2015 the bilateral trade between China and Kazakhstan is expected to reach $\$ 40$ billion, ${ }^{17}$ an increase that will further strengthen China's foothold in Central Asia.

Much to Moscow's dismay, improvements in Kazakhstani-Chinese economic relations are expected to increase even further in the years to come. At the end of September 2011, Chinese and Kazakhstani business people met to discuss investment projects between the two countries. The chairman of the Standing Committee of China's National People's Congress, Wu Bangguo, who attended the meeting, focused the talks on future cooperation possibilities in energy, mineral extraction, metallurgy, road and railway construction, telecommunications and agriculture. He also drew attention to the need to improve cooperation between Kazakhstani and Chinese firms and augment the volume of investments. ${ }^{18}$ Perhaps more importantly, Bangguo insisted that there are many opportunities for cooperation in manufacturing and service sectors.

Since independence, Kazakhstan's president has been adamant about the necessity to diversify the Kazakhstani economy away from energy production and export, as this makes the country too dependent on fluctuating oil and gas prices. A rapidly developing partner like China would certainly help President Nazarbayev achieve this objective. However, one can only be doubtful whether Chinese investments and cooperation will actually bring about economic diversification in Kazakhstan. The Kazakhstani elite, on which this process of diversification depends heavily, may not actually have a strong enough interest in altering the present economic structure. Kazakhstan's historical experience has demonstrated that poorly diversified economies, which rely heavily on natural resources for generating revenues, are the best models political and economic elites can use to indulge in kleptocracy. ${ }^{19}$ It remains to be seen whether the Kazakhstan-China economic partnership will serve the interests of ordinary Kazakhstanis or merely the members of the president's circle.

\section{Energy cooperation}

Energy development and export largely dominates Kazakhstani-Chinese relations. Beijing considers Central Asia, especially Kazakhstan and Turkmenistan, a crucial element in its energy equation and has geared its policy in such a way as to secure as many resources as possible from this region. ${ }^{20}$ Central Asia can play a major role 
in helping Beijing diversify its energy suppliers. It can also reduce, by the same token, China's reliance on Middle East oil exporters, who exported to China more than two million barrels/day in 2010. ${ }^{21}$ Beijing keeps a close eye on the current political events in the Middle East, and the instability that comes with them. Chinese policy planners develop alternative policies which could be implemented in the event that the United States decides to close, or at least filter, the Strait of Malacca, through which oil cargoes from the Middle East must pass. ${ }^{22}$ Under these circumstances, China's oil and gas imports from Central Asia will probably continue over the next few years-even potentially for decades - prompting the expansion of the energy sectors of the Central Asian hydrocarbon-rich states. Furthermore, Chinese imports of Central Asian oil and gas will divert a massive amount of revenue from China to Central Asia, in addition to providing a powerful alternative buyer to Russia. ${ }^{23}$ This will in turn give Central Asian governments more political leeway in their international relations. Kazakhstan seems quite conscious of this situation, and is accordingly currying favour with China, knowing the many benefits it could potentially reap.

The spectacular economic growth in the People's Republic of China (PRC) in the last 20 years has generated intensive use of primary energy resources. Since the first half of the 1990s, China has not been able to meet all its energy needs from its own production and has thus become a net importer of oil and gas. The country became a net importer of natural gas in 2008 as the gap between supply and demand approached five billion cubic metres. Meanwhile, Kazakhstan and Turkmenistan, and to a lesser extent Uzbekistan, have abundant reserves of oil and are export-oriented economies. Therefore, the Chinese authorities have progressively made energy a priority issue on their Central Asian agenda. This development has important implications and can be analysed from various angles. Firstly, China's own perspective on its present boom and how Beijing's involvement in the Central Asian republics' development is perceived need to be taken into consideration. Secondly, the growing role of Central Asian energy issues in China's policy has important geopolitical implications, specifically on the relations between Moscow and Beijing. Energy is one of the strategic issues where the interests of Beijing and Moscow are clearly divergent and it has the potential to complicate the cooperative atmosphere the two powers have enjoyed in recent years. Moreover, it is necessary to contextualise the Caspian Basin's place within the overall energy strategy of the PRC.

Kazakhstan has become one of China's main energy suppliers. In 2011, 11 million tons of oil flowed to China through the Kazakhstan-China oil pipeline, which runs from Kazakhstan's Caspian shore to Xinjiang in China. ${ }^{24}$ During a September 2011 visit to Central Asia, Chinese officials expressed their desire to expand energy trade with oilrich Kazakhstan. ${ }^{25}$ The latter's oil exports are set to swell over the next few years. Astana is expecting a 50 per cent increase by $2020,{ }^{26}$ and China will receive the lion's share of this, as its domestic demand is increasing dramatically. Kazakhstan plans to export 22 million tons/year of oil to China by 2020, up from 12.1 million tons in $2011 .^{27}$ To achieve this, it is currently boosting the export capacity of the KazakhstanChina pipeline and constructing a parallel gas pipeline scheduled for completion by 2014. ${ }^{28}$ This additional pipeline will also enable Kazakhstan to transport gas extracted in the western part of the country, where most of the deposits are located, to the more industrialised southern regions, reducing by the same token their reliance on Uzbek gas imports. ${ }^{29}$

As in other areas, the purchase of oil deposits and the signing of long-term energy supply contracts are the main instruments used by China to influence the energy sector 
of Central Asian states. In 1997, after three years of negotiations, the China National Petroleum Corporation (CNPC) began operating in Kazakhstan. Other major Chinese firms soon followed. In addition, Beijing and Astana signed in that year an agreement to construct a pipeline of almost 4,800 km connecting the Caspian Sea and the Xinjiang region in north-west China.

The construction of the Kazakhstan-China oil pipeline was divided into three sections. The first section, linking Atyrau (north Caspian) with Aktobe region oil fields (western Kazakhstan) was completed in March 2003. This section also carries oil to the west, towards the Caspian Pipeline Consortium (CPC) pipeline, which connects the Tengiz oil field in Kazakhstan with the Russian port of Novorossiysk on the Black Sea, through Atyrau. The second 1,000-km section was built between September 2004 and December 2005 and links Atasu in central Kazakhstan to the border town of Alashankou in China's Xinjiang Uygur Autonomous Region. Like all other milestones in China's Central Asian energy development, the opening of this section of nearly 1,000 miles generated much debate and some stridency. However, the Atasu-Alashankou section, the most important of the Kazakhstan-China oil pipeline, is able to deliver only 10 million tons of crude oil a year to China, a modest amount considering China's oil needs. The third and final section, which connects Kenkiyak with Kumpol, was as per an agreement between Kazakhstan and China on 18 August 2007 and completed on 11 July 2009. This pipeline makes it possible to pump oil directly from the northern Caspian to the Dushanzi refinery in Xinjiang.

To feed the pipeline, China has acquired, through various companies, exploitation rights to various oil fields in Kazakhstan. In the process Chinese companies have had to cope with both the suspicion their presence arouses and the relative delay in getting anything done, thus harming their position in the coveted Kazakh Caspian offshore fields. The exception is the Darkhan deposit, which they exploit under an agreement signed in October 2008. However, making a virtue of necessity and following a consistent business strategy, China has invested in oil fields located in the Aktobe region and in other more isolated sites along the route of the Sino-Kazakh oil pipeline (Buzachi North, Karazhanbas and Kumkol in the Kyzyl-Orda region). ${ }^{30}$ These, along with the aforementioned Atasu connection to the pipeline going to Russia, make the SinoKazakh oil pipeline an alternative route for exporting Russian oil from western Siberia to China. As a result, Beijing has virtually assured sources of supply for a pipeline which currently has a maximum annual capacity of 20 million tons of crude that could be expanded to 30 .

The most significant Chinese investments in the Kazakh hydrocarbon sector have been the $\$ 4.2$ takeover of PetroKazakhstan, a Canadian-based company, by the Chinese oil company CNPC in August 2005 and the purchase for US\$1.91 billion of the Kazakhstan oil assets of Canada's Nations Energy Company Ltd by the China International Trust and Investment Corporation (CITIC) in December 2006. Through these two acquisitions Beijing acquired an important position in the Kazakh oil market and although the figures available vary substantially and are difficult to compute, it is estimated that in 2006 China was responsible for about 25 per cent of all oil extraction in Kazakhstan. ${ }^{31}$

This increase in China's presence in the Kazakh oil sector generated an animated public debate led by those who see in Beijing's policy a growing threat to Kazakhstan's economic sovereignty and autonomous development prospects. While some local analysts are known to dissent from the majority view and point out, for example, that 
contracts signed with Chinese companies are more beneficial to Kazakhstan than those signed with large Western companies, the controversy over the Chinese acquisitions has more particularly culminated in the Majlis, the parliament of Kazakhstan, which approved in September 2007 the introduction of a series of amendments to the law 'on subsurface and the use of the subsurface' dated 27 January 1996. The law expanded Astana's ability to revise or annul contracts concerning the exploitation of subsurface resources and posing a threat to 'national economic security interests'. ${ }^{32}$ As a response to the $\$ 1.9$ billion sale of the Karazhanbas oil field by Canada-based Nations Energy to CITIC, the Kazakh government passed a law preventing foreign investors from selling stakes in Kazakhstan's assets to third parties. Also, the 2005 sale of PetroKazakhstan Inc. to CNPC illustrated the need for the new law giving Kazakhstan the first right of refusal to buy assets in any proposed transfer of oil assets between foreign companies. Also, KasMunaiGas became a stakeholder in PetroKazakhstan in 2005, and following the passage of this amendment, KasMunaiGas executed an agreement with CITIC to purchase 50 per cent of Karazhanbas. It is interesting to note that the above PetroKazakhstan purchase created a similar reaction in Russia, especially among companies active in Kazakhstan, which share these misgivings about the progressive Chinese encroachment.

The purchase of the Canadian firm by CNPC led to the Russian company Lukoil, which owns 25 per cent of the rights to the North Kumkol deposit, to go to both the Court of International Arbitration in Stockholm and the Kazakh courts to claim a preferential right to acquire the deposit. Through this action, Lukoil, which won the lawsuit, secured the rights to the entire reservoir. Lukoil is officially a private oil company but its actions, as is well known in the energy industry, are often in line with the wishes of the Kremlin. Therefore, some authors believe that this action shows that 'Russia is unwilling to allow China to have direct access to Central Asian energy resources'. 33

Within the SCO, which is paying increasing attention to energy issues, the approaches of Kazakhstan and Russia coincide. Despite the fear of potential dominance, Kazakhstan estimates that China's presence in its oil sector is of strategic importance in the long term. The Kazakhstan-China oil pipeline has already reduced Kazakhstan's dependence on the old Soviet pipeline network through which the majority of Kazakh oil exports still flow. The new pipeline allows direct access to the global economy, with its ever expanding oil consumption. Moreover, the weight of Chinese companies in the sector, though increasing, is still small in relative terms and barring new purchases of large deposits, their share in total Kazakh production will decrease significantly when the extraction of oil from the offshore Kashagan field, situated in the northern part of the Caspian Sea, begins. ${ }^{34}$

While energy will undoubtedly remain the nucleus of China-Kazakhstan cooperation, Chinese officials hope that in future this cooperation will not remain limited to oil and gas; they believe that it should be extended to clean and renewable energy as well. ${ }^{35}$ In that regard, Beijing has singled out nuclear energy as a potentially important sector for bilateral cooperation. In 2011 Kazakhstan, which is well endowed with uranium ore, began exporting the indispensable resource for producing nuclear energy to China. ${ }^{36}$

These developments can only benefit Kazakhstan, as it requires new trading partners if it is to become one of the top five oil producers in the world. ${ }^{37}$ President Nazarbayev has also committed his country to diversifying the economy, which can be achieved through major investment in the renewable energy sector. 


\section{Security cooperation}

Security is a top priority in China's Central Asian strategy. During his meeting with Nazarbayev in summer 2011, President Jintao stressed the importance of security. He particularly outlined what he considers the three main 'evils' in Central Asia: separatism, extremism and terrorism. ${ }^{38}$ The list is not surprising, as it reflects Beijing's preoccupation with the destabilising activities in Xinjiang, a turbulent Chinese autonomous region, which has experienced sporadic outbursts of social violence. The Muslim and Turkic Uyghur, who constitute the majority of the population, claim that their region is a victim of Chinese discrimination, colonialism and oppression. ${ }^{39}$ The July 2011 explosion of violence cast a shadow of pessimism over long-lasting stability in Xinjiang. ${ }^{40}$ Xinjiang is a strategic region for China, as all Central Asian oil and gas pipelines linking the eastern part of China to Central Asia run across that territory. The eruption of violence in this strategic territory could adversely impinge on Chinese oil imports and put at risk Beijing's energy security.

It is no wonder then that the Chinese leadership is manifestly fearful of instability and religiously motivated terrorism, as evidenced by China's vigorous pleas to enhance the role of the SCO to ensure regional stability. ${ }^{41}$ In this respect, security is more and more a determining factor in the relations between China and Kazakhstan, and in the short term it will have an increasingly important part to play within the SCO. ${ }^{42}$ Some Kazakhstani observers, however, believe that Kazakhstan-China cooperation is actually much more a showcase of Beijing's diplomatic skills than a bona fide desire to establish friendly relations, while respecting Kazakhstan's sovereignty. They argue that true cooperation within the SCO will be difficult to achieve because Russia is unlikely to let the Central Asian states, with which it has strong and historical ties, drift away towards China without resistance. ${ }^{43}$

For Beijing, the best way to promote security may actually be through deeper economic cooperation with Astana. China's policies towards the five republics of Central Asia seek quite unequivocally to integrate Xinjiang's economy with those of Central Asian states. ${ }^{44}$ The Chinese often emphasise that the westernmost Chinese region shares deep cultural roots with Kazakhstan and that a trade partnership can only benefit the two, and the regions beyond. Bangguo, for instance, called the Khorgos centre a powerful opportunity to improve trade between Kazakhstan and China's western regions and increase cooperation at the regional level. ${ }^{45}$ Beijing is currently implementing an ambitious plan to improve economic conditions in Xinjiang, reduce instances of social unrest and alleviate the frustration of the local Uyghur population. Kazakhstan's further economic integration into the Chinese north-west region has the potential to strengthen security through economic prosperity for an unpredictable and strategically pivotal region.

\section{Risky diversification}

A lack of diversification and a dependence on oil and gas exports are the two main problems of the Kazakhstani economy. China's investments in the secondary and tertiary economic sectors may prove the correct means to overcome these obstacles and gear the Kazakhstani economy towards the production of value-added manufactured goods.

It could permit Kazakhstan to avoid what the economist Barry Eichengreen calls the 'middle-income trap', which can occur in countries with a small population, like Kazakhstan, and abundant oil and gas. This situation usually leads to high incomes 
with not much effort in terms of industrial innovation and economic efficiency. ${ }^{46}$ Eichengreen found that when a country's per capita GDP rises to somewhere between $\$ 1,000$ and $\$ 12,000$ per person measured in 2010 dollars, its economy suddenly stalls and annual growth falls by at least two percentage points a year. It gets stuck in the lowest end of the middle. Countries in that situation hit the wall because easy gains out of low-productivity sectors (oil and gas) and in higher-productivity sectors, as well as from technology transfers, have reached the exhaustion point. This is exactly where Kazakhstan is perched. A country with a limited number of comparative advantages will be caught in the middle income and the constant policymaking uncertainty resulting from hydrocarbon price fluctuation.

Escaping the middle-income trap, as a country like South Korea has done, requires the creation of a functioning, competitive large-scale internal economy. Astana at least has a sense of the importance of this goal since the 2011 presidential election. Nazarbayev's election programme was known as 'Kazakhstan 2030', with the slogan 'Let's Build the Future Together'. ${ }^{47}$ Whether the Kazakhstani elite can pull it off is a matter for debate.

Developing closer trade relations with China entails risks for Kazakhstan. There is an ongoing debate as to the ability of the Chinese economy to maintain during the next five to 10 years growth rates as high as those experienced during the first decade of the 21 st century. For Kazakhstan, beneficial economic cooperation with China will ultimately depend on its neighbour's prosperity. For many years, economic analysts, in both China and the West, have been warning policymakers about the pitfalls of an overheating Chinese economy. ${ }^{48}$

Ambrose Evans-Pritchard, an economic analyst for The Telegraph, keeps repeating, often in a quite pessimistic way, that China may face the problems of household over-expenditure in the not-too-distant future. ${ }^{49}$ Forbes analyst Shaun Rein, on his part, has for years been warning about a looming dot-com bubble in China, ${ }^{50}$ a dangerously increasing inflation rate, real estate problems and US-China trade tensions. ${ }^{51}$ The 2010 World Economic Forum and Bloomberg's analysts have also identified worrying signals of economic overheating. ${ }^{52}$ Even though the odds are low for a 'hard landing', this scenario cannot be ruled out completely. ${ }^{53}$

The Kazakhstani economy is expected to become more and more dependent on China's investments, manufactured goods and energy imports. It runs the risk of being exposed to a dependence on one all-powerful partner, as well as this partner's economic fortunes or misfortunes. All in all, this would mean substituting a dependency on hydrocarbon exports for a dependency on a single trading partner. Oddly enough, this hazard may be averted because authoritarian regimes are notoriously wary of a too strong bilateral and multilateral cooperation. In effect, Astana is, to some extent, cautious about China's plans for the region, and consequently prefers to adopt a gradualist approach in Kazakhstan-China bilateral relations rather than to let Beijing move in on Kazakhstan's assets in one big swoop. ${ }^{54}$

Astana under Nazarbayev has put in a lot of effort to enhance the Kazakhstani economic presence in the West and the former Soviet republics. In fact, one of the main features of Kazakhstan's foreign policy is the so-called 'multi-vector' approach, which seeks to advance Kazakhstan's national interests by balancing those of the West, Russia and China, and 'integration and openness to the entire world'. ${ }^{55}$ It follows that Kazakhstani embassies and delegations abroad are actively committed to attracting investment from all corners of the world. Such activism is remarkable in many respects, especially as it is achieving concrete results. However, when Kazakhstan's geographic 
location is factored in, any optimism about the country's long-term prospects for development and prosperity is somewhat dampened. Despite its size (it is the world's ninth largest country), Kazakhstan is landlocked and abuts two colossal economic partners, Russia and China. Other Central Asian states are in no way capable of offering comparably promising opportunities for economic cooperation. This largely explains why Astana has embarked on a journey to elevate Kazakhstan to the status of 'great power' in the Eurasia region, while keeping windows open in the direction of the West.

\section{Chinese migration}

If Chinese investments and low-price goods are generally greatly welcomed by both Central Asian governments and their citizens, the same cannot be said about Chinese immigration, temporary or permanent. Complaints about incoming Chinese workers are being heard more and more throughout Central Asia. Sometimes Central Asians' criticism is even directed at Chinese immigrant workers who build strategic infrastructures, which would never see the light of day without China's financial and logistic input. Such negative sentiments are particularly strong in Kazakhstan, whose low population size and density pale in comparison with those of prosperous China. An increasing number of Kazakhstanis are fearful of a Chinese demographic expansion in their country. Many also accuse Beijing of conspiring to colonise Central Asian countries. ${ }^{56}$ Chinese attempts to lease a vast swath of Kazakhstani land in 2010 were not well received by the local population, and this led to fierce and unusually large-scale protests. ${ }^{57}$ Kazakhstanis are afraid that what awaits them is a demographic situation resembling that of the Uyghurs in the Xinjiang autonomous region, which lies just across the border, where the majority status of Uyghurs in the total population has been progressively reduced as a result of a massive influx of ethnic Han, who are set to become the majority in the not-so-distant future. ${ }^{58}$ Astana cannot afford to ignore the possibility of such a scenario unfolding in Kazakhstan as well, as it could prove a powerful impediment to economic integration between the two countries.

\section{A double dilemma for Kazakhstan}

Kazakhstani political authorities may have to face a harrowing policy dilemma. They will have to either fully open up the country to China's economic projects and become more and more dependent on the economic performance of a neighbour that will soon have a GDP approximately 100 times larger than that of Kazakhstan, or put up legal and economic ramparts against Beijing's foreign policy manoeuvres and limit itself to pocketing only a fraction of the potential benefits that could be brought about by closer bilateral relations. The Kazakhstanis' growing feelings of hostility towards Chinese penetration undoubtedly make it harder for Astana to solve this dilemma.

Niklas Swanstrom, director of the Stockholm-based Institute for Security and Development Policy, is one analyst who believes that China-Kazakhstan relations will not develop much further than their current level, precisely because Nazarbayev and his entourage seem uninterested in setting in motion closer cooperation. ${ }^{59}$

\section{Conclusion}

Overall, China-Kazakhstan political and economic cooperation has achieved impressive successes. The two countries are developing ties primarily in the energy sphere, 
while China seems to be encouraging Kazakhstan's economic diversification. However, to diversify the Kazakhstani economy, Chinese investment alone may not be sufficient. Astana has to demonstrate a strong political will to successfully alter the economic structure, even though this may deprive the 'oligarchs' of their control over whole business sectors. Kazakhstan's cooperation with China on security-related matters has economic dimensions, which may ultimately prove to be more crucial than pure mutual military assistance. In fact, Kazakhstan could become an indispensable ally in Beijing's efforts to quell social unrest in Xinjiang. The Kazakhstan-China economic integration will rub off on both countries to Xinjiang's benefit. In this regard, the promotion of trade in border areas is particularly important.

There are drawbacks associated with further cooperation, however. Depending too much on China may be dangerous for Kazakhstan. A serious economic downturn experienced by China would spill over to Kazakhstan, much in the same way that an economic recession in the United States always has deep consequences for Canadian markets and exporters. Moreover, the two countries might be close to reaching the limits of their cooperation. The wariness of Kazakhstani officials over China's growing power and the local population's fear of the Chinese demographic expansion may prove to be insurmountable obstacles to future cooperation between the two countries. In any event, Kazakhstan's national economic problems are unlikely to be solved in the near future.

\section{Notes}

1. 'Kazakhstan', Central Intelligence Agency-The World Fact Book, at https://www.cia.gov/ library/publications/the-world-factbook/geos/kz.html (Accessed 12 March 2012).

2. 'International Human Development Indictors', UNDP Human Development Reports, at http:// hdr.undp.org/en/statistics/ (Accessed 12 March 2012). All other Central Asian countries are ranked among those with a medium human development level.

3. Anna Stroganova, “Монд”: Дорогой наш Казахстан' ['Le Monde': Our Dear Kazakhstan], Radio France International, at http://www.russian.rfi.fr/tsentralnaya-aziya/ 20110919-mond-dorogoi-nash-kazakhstan (Accessed 21 September 2011).

4. Marijus Radvilas, “'Kazakhstan's Way” of Development', European Dialogue, at http:// eurodialogue.org/Kazakhstan-way-of-development (Accessed 12 February 2012).

5. 'Central Asia: Decay and Decline', International Crisis Group, Asia Report No. 201, 3 February 2011, at http://www.crisisgroup.org/en/regions/asia/central-asia/201-central-asiadecay-and-decline.aspx (Accessed 25 February 2011).

6. Ibid.

7. 'China-Kazakhstan Relations Grow Stronger', China Daily, 15 October 2007, at http://www. chinadaily.com.cn/cndy/2007-10/15/content_6173531.htm (Accessed 29 November 2011).

8. 'China, Kazakhstan Upgrade Relationship', People's Daily Online, 14 June 2011, at http:// english.peopledaily.com.cn/90001/90776/90883/7409016.html (Accessed 29 November 2011).

9. 'China-Kazakhstan Relations Grow Stronger', no. 7.

10. The Editors, 'Global Insider: China-Kazakhstan Relations', World Politics Review, 1 March 2011, at http://www.worldpoliticsreview.com/trend-lines/8044/global-insider-chinakazakhstanrelations (Accessed 24 January 2012).

11. Leslie Hook and Isabel Gorst, 'Kazakhstan Embraces Chinese Investments', Financial Times, 22 February 2011, at http://www.ft.com/intl/cms/s/0/8c25e008-3e5e-11e0-9e8f-00144feabdc0. html\#axzz1bW48APVR (Accessed 21 October 2011).

12. The Editors, no. 10.

13. Roger McDermott, 'Kazakhstan Looks East: Sino-Kazakh Strategic Partnership Deepens', Eurasia Daily Monitor, 5 July 2011, at http://www.jamestown.org/single/?no_cache=1\&tx ttnews[tt_news] $=38135 \& \mathrm{tx} \_t$ tnews[backPid] $=381 \& \mathrm{cHash}=059 \mathrm{dceab} 78 \mathrm{bc} 4 \mathrm{~d} 5 \mathrm{cf} 160 \mathrm{~d} 377 \mathrm{fefff}$ 2a9 (Accessed 14 September 2011). 
14. Svetlana Shesterneva, 'The Prime Minister Acquainted with the Project ICBC "Horgos"', Khorgos, at http://mcps-khorgos.kz/en/smi-review/prime-minister-acquainted-project-icbchorgos\%E2\%80\%9D (Accessed 8 March 2012).

15. Roger McDermott, no. 13.

16. 'China-Kazakhstan Relations', no. 7.

17. Roger McDermott, no. 13.

18. 'Wu Bangguo Attends the Symposium of Chinese and Kazakh Entrepreneurs', Ministry of Foreign Affairs of the PRC, 27 September 2011, at http://www.fmprc.gov.cn/eng/zxxx/t863262. htm (Accessed 3 November 2011).

19. Bruce Bueno De Mesquita et al., The Logic of Political Survival, The MIT Press, Cambridge, MA, 2003, pp. 93-95.

20. Edward Wong, 'China Quietly Extends Footprints into Central Asia', The New York Times, 2 January 2011, at http://www.nytimes.com/2011/01/03/world/asia/03china.html? pagewanted=all (Accessed 3 November 2011).

21. 'China', EIA - US Energy Information Administration, November 2010, at http://www.eia.gov/ countries/cab.cfm?fips $=\mathrm{CH}$ (Accessed 21 October 2011).

22. Edward Wong, no. 20.

23. 'China's Hu Kicks Off Central Asian Energy Tour', Radio Free Europe/Radio Liberty, 12 December 2009, at http://www.rferl.org/content/Chinese_Leader_To_Open_Central_Asia_ Gas_Pipeline/1902021.html (Accessed 6 November 2011).

24. Roger McDermott, no. 13.

25. 'Kazakhstan, China to Expand Energy Co-operation', Central Asia Online, 10 September 2011, at http://centralasiaonline.com/cocoon/caii/xhtml/en_GB/features/caii/newsbriefs/2011/ 09/10/newsbrief-01 (Accessed 12 March 2012).

26. 'Oil Exports to Balloon by 2020, Kazakh Minister Says', Universal Newswires-Central Asia Newswire, 4 October 2011, at http://www.universalnewswires.com/centralasia/viewstory. aspx?id=10329 (Accessed 12 March 2012).

27. Ibid.

28. 'Country Analysis Briefs - Kazakhstan', EIA-US Energy Information Administration, November 2010, at http://www.eia.gov/emeu/cabs/Kazakhstan/pdf.pdf (Accessed 26 February 2012).

29. 'Kazakhstan', EIA - US Energy Information Administration, November 2010, at http://www. eia.gov/countries/cab.cfm?fips=KZ (Accessed 7 February 2012).

30. For more details see Sebastien Peyrouse, 'Chinese Economic Presence in Kazakhstan', China Perspectives, 3, 2008, pp. 43-45.

31. Ibid.

32. S. Akhmetova, S. Daumov and T. Yuldabayev, 'Review of the Draft Law of the Republic of Kazakhstan "On Subsurface and Subsurface Use", Oil, Gas \& Energy Law (OGEL), 2, 2010, at www.ogel.org/article.asp?key=3008 (Accessed 8 September 2012).

33. Artyom Matusov, 'Energy Cooperation in the SCO: Club or Gathering?', Central AsiaCaucasus Institute, The China and Eurasia Forum Quarterly, 5(3), 2007, p. 95.

34. Kimberly Marten, 'Disrupting the Balance: Russian Efforts to Control Kazakhstan's Oil', The Program on New Approaches to Research and Security in Eurasia (PONARS Eurasia), PONARS Policy Memo No. 428, December 2006, at http://www.ponarseurasia.org/memo/ disrupting-balance-russian-efforts-control-kazakhstans-oil.

35. Roger McDermott, no. 13.

36. Wang Ying, 'China, Kazakhstan to Cooperate on Nuclear, Alternative Energy, Pipelines', Bloomberg, 14 June 2011, at http://www.bloomberg.com/news/2011-06-14/china-kazakhstanto-expand-energy-relations-pledge-regional-coordination.html (Accessed 12 February 2012).

37. 'Country Analysis Briefs-Kazakhstan', no. 28.

38. 'China Issues 1st Evaluation Report on SCO', China Daily, 26 September 2011, at http://www.chinadaily.com.cn/usa/business/2011-09/26/content_13792322.htm (Accessed 13 January 2012).

39. See the database run by the World Uyghur Congress, at http://www.uyghurcongress.org/en/.

40. Richard Rousseau, 'Competing Geopolitical Interests of China, Russia and the United States in Central Asia and the Caspian Region', Khazar Journal of Humanities and Social Sciences, 14(3), 2011, pp. 13-30, at http://dspace.khazar.org/jspui/bitstream/123456789/ 1367/1/02R\%20Rousseau\%20-\%20Competing\%20Geopolitical\%20Interests\%20of\%20China \%20Russia\%20-\%20Khazar\%20Journal.pdf (Accessed 5 January 2012). 
41. 'SCO Stresses Co-op against Terrorism', China Daily, 4 October 2011, at http://www. chinadaily.com.cn/usa/china/2011-10/04/content_13835649.htm (Accessed 3 November 2011).

42. The Editors, no. 10 .

43. Konrad Muller, 'Kazakh-China Diary: Ablai Khan, Train Gauges and a Piece of Paper', The Interpreter, 29 September 2011, at http://www.lowyinterpreter.org/post/2011/09/29/KazakhChina-diary-Ablai-Khan-and-a-piece-of-paper.aspx (Accessed 4 November 2011).

44. Edward Wong, no. 20.

45. 'Wu Bangguo Attends the Symposium', no. 18.

46. Barry Eichengreen, Donghyun Park and Kwanho Shin, 'When Fast Growing Economies Slow Down: International Evidence and Implications for China', NBER Working Paper No. 16919, March 2011, at http://www.nber.org/papers/w16919.

47. A. Maratov, 'Nazarbayev's Election Program to Be Strategy "Kazakhstan 2030", Trend, 2 November 2011, at http://pda.trend.az/en/1827592.html (Accessed 7 February 2012).

48. As early as 1999, He Qinglian warned about the risks related to multiple 'bubbles' developing within China's fast growing economy. See He Qinglian, 'China's Latent Economic Crisis and Potential Risks', Modern China Studies, 65(2), 1999, pp. 65-81.

49. Ambrose Evans-Pritchard, 'China Has Now Become the Biggest Risk to the World Economy', The Telegraph, 15 November 2009, at http://www.telegraph.co.uk/finance/ comment/ambroseevans_pritchard/6575883/China-has-now-become-thebiggest-risk-to-theworld-economy.html (Accessed 7 February 2012); 'Overheating East to Falter Before the Bankrupt West Recovers', The Telegraph, 3 January 2011, at http://www.telegraph.co.uk/ finance/comment/ambroseevans_pritchard/8230654/Overheating-East-to-falter-beforethebankrupt-West-recovers.html (Accessed 7 February 2012).

50. Shaun Rein, "A Dangerous Bubble Is Emerging in China", Forbes, 23 November 2010, at http://www.forbes.com/2010/11/23/china-tudou-youkou-video-bubble-leadership-managingrein_2.html (Accessed 7 February 2012).

51. Shaun Rein, 'Three Big Risks to China's Economy in 2011', Forbes, 5 January 2011, at http://www.forbes.com/2011/01/05/china-economy-corruption-leadership-citizenshiprein_2.html (Accessed 7 February 2011).

52. See for example Zijing $\mathrm{Wu}$ and Kevin Crowley, 'China's Overheating Economy is "Major" Risk, WEF Says', Bloomberg, 14 January 2010, at http://www.bloomberg.com/ apps/news?pid=newsarchive \&sid=aevGlBpJ6gW8 (Accessed 7 February 2012); Dexter Roberts, 'China's Economy Facing Risks, Warn Officials', Businessweek, 5 January 2010, at http://www.businessweek.com/globalbiz/blog/eyeonasia/archives/2010/01/chinas_economy_ 4.html (Accessed 8 February 2012).

53. For more details, see Pieter Bottelier, 'Will China Ride Out of the Storm?', Carnegie Endowment For International Peace, International Economic Bulletin, 15 September 2011, at http://carnegieendowment.org/2011/09/15/will-china-ride-out-storm/54xp (Accessed 10 February 2012).

54. The Editors, no. 10 .

55. 'Kazakhstan to Pursue Multi-Vector Foreign Policy', Interfax-Kazakhstan, 8 April 2011, at http://www.interfax.kz/?lang=eng\&int_id=expert_opinions\&news_id=365 (Accessed 1 March 2012).

56. Edward Wong, no. 20.

57. Joanna Lillis, 'China Looking to Lease Lands for Agricultural Purposes', Eurasianet, 3 February 2010, at http://www.eurasianet.org/departments/insight/articles/eav020410.shtml (Accessed 12 February 2012).

58. Stanley Toops, 'Demographic and Development in Xinjiang after 1949', East-West Center, Washington, DC, May 2004, at http://www.eastwestcenter.org/fileadmin/stored/pdfs/ EWCWwp001.pdf (Accessed 5 January 2012).

59. The Editors, no. 10. 